\title{
Article
}

\section{What do we mean by 'systematic' in health education systematic reviews and why it matters!}

Gordon, Morris, Daniel, Michelle and Patricio, Madalena

Available at http://clok.uclan.ac.uk/24409/

Gordon, Morris ORCID: 0000-0002-1216-5158, Daniel, Michelle and Patricio, Madalena (2019) What do we mean by 'systematic' in health education systematic reviews and why it matters! Medical Teacher, 41 (8). pp. 956-957. ISSN 0142-159X

It is advisable to refer to the publisher's version if you intend to cite from the work. http://dx.doi.org/10.1080/0142159x.2018.1504164

For more information about UCLan's research in this area go to http://www.uclan.ac.uk/researchgroups/ and search for < name of research Group>.

For information about Research generally at UCLan please go to http://www.uclan.ac.uk/research/

All outputs in CLoK are protected by Intellectual Property Rights law, including Copyright law. Copyright, IPR and Moral Rights for the works on this site are retained by the individual authors and/or other copyright owners. Terms and conditions for use of this material are defined in the policies page.

\section{CLoK}

Central Lancashire online Knowledge www.clok.uclan.ac.uk

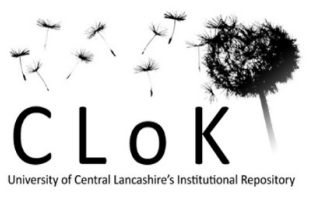




\section{What do we mean by 'systematic' in health education systematic reviews and why it matters!}

Morris Gordon, MBChB, PhD, MMed, Michelle Daniel, MD, MHPE, Madalena Patricio PhD,

Short title: What do we mean by 'systematic' reviews?

Morris Gordon, MBChB, PHD, MMed is a Reader in medical education and evidence

synthesis, University of Central Lancashire, Preston, UK. Orchid.org/0000-0002-1216-5158

Michelle Daniel MD, MHPE is Assistant Dean for Curriculum, and Associate Professor of

Emergency Medicine and Learning Health Sciences at the University of Michigan Medical

School in Ann Arbor, Michigan, USA. Orcid.org/0000-0001-8961-7119

Madalena Patricio, PhD, is Director of the Department of Medical Education at the

Faculdade de Medicina da Universidade de Lisboa, Portugal

\section{Contact information (corresponding author)}

Morris Gordon, HA115, Harrington building, University of Central Lancashire, Preston, UK, Tel 01772201 201, mgordon@uclan.ac.uk 
For anyone who reads the health education literature regularly, journal sections that focus on 'reviews' are common, yet the use of the term 'systematic' to describe these reviews is sporadic. Further, we believe this term is used in a manner in the field that does not accurately reflect the methodological implications of the term in this context. There are examples of 'systematic' works that simply don't describe themselves in that way, despite a clear alignment with many of the principles of 'systematic reviewing'. Conversely, there are reviews that are clearly not systematic, yet describe themselves as such. In this piece, we discuss how this difficulty with methodological nomenclature has occurred and the distinct and important meaning of the term 'systematic' in relation to health education reviews.

For the past two decades, there have been calls for medical education to become more evidence-based (Van Der Vleuten 2000), in keeping with the systematic review tradition that underpins evidence based medicine (EBM) (Bligh 2000). Using a systematic approach moves past eminence based works with their associated risks of bias. In 1999, the Best Evidence Medical Education (BEME) Collaboration was founded to address such issues, with the goal to disseminate evidence in the form of reviews that can guide evidence informed education and create a culture of best evidence education across the field. In conceptualising its role, BEME cited the EBM movement, as exemplified by the work of the Cochrane Collaboration (Harden 1999). Since then, much of the focus of BEME has been on developing processes and systems used to search, appraise and synthesize research evidence. BEME search and 
data extraction procedures are essentially grounded in the positivist traditions of the Cochrane Collaboration, to ensure a systematic process to distill 'best evidence education'.

Positivism, as a research paradigm, views knowledge derived from empirical evidence as an authoritative truth. While this grounding was deemed vital to the detailed processes that formed the basis of BEME, it has led to some readers in the field raising concerns with the appropriateness of such an alignment in health education. Systematic reviews are so synonymous with the Cochrane approach that these terms are seen as inextricably linked. This has been particularly problematic for those in health education seeking to embrace different forms of reviews using a wider range of synthesis methods to generate best evidence. However, the impact that can be seen is exemplified in a recent published example by Castillo et al (2018). This study describes itself as a critical narrative review and does not use the term 'systematic'. In fact, the authors go to lengths to state the review was 'based on a systematic search strategy...By contrast with the results of a systematic review, which is designed to provide an answer relevant to a single, empirical question, we aimed to gain a richer understanding of the concept of knowledge transfer in the context....'.

Some researchers in the field clearly believe that certain review types, such as realist, narrative or scoping reviews are not compatible with the positivist tradition of 'systematic' review searching. At the heart of this argument is the perception of a paradoxical misalignment of the positivist tradition of the 'systematic' review and the constructivist tradition of the methodologies currently being applied to synthesis within this wider landscape of review choices. Observant users of BEME reviews may have noted this tension by the removal of the stipulation for the inclusion of the term 'systematic' in the title of 
BEME reviews. Many reviews published outside of the BEME collaboration also

inconsistently use the term 'systematic' to describe their review when they are not aligned with a systematic approach. There is therefore a problem not just with nomenclature, but the meaning behind the term in different contexts. This ambiguity raises the key question of the paper - what do we mean by the term 'systematic' within education reviewing and does the use of this term actually matter?

We believe that the term 'systematic' when used in health education reviews clearly describes a search and extraction process that has its grounding in a positivist tradition similar to Cochrane but is not in any way incompatible with the array of evidence synthesis methods or alternative review traditions that can be used in the field. Table 1 presents the key elements of a range of review types. This identifies that in key areas, including search strategies and inclusion criteria, where there is almost universal alignment with a 'systematic' approach, clearly identified in methodological papers describing the techniques (Jahan et al. 2016, Peterson et al. 2017, Wong et al. 2013).

\begin{tabular}{|c|c|c|c|c|c|}
\hline & $\begin{array}{l}\text { Clinical medicine } \\
\text { Systematic } \\
\text { review (e.g. } \\
\text { Cochrane) }\end{array}$ & $\begin{array}{l}\text { Health Education } \\
\text { Systematic } \\
\text { review (e.g. } \\
\text { BEME) }\end{array}$ & $\begin{array}{l}\text { Scoping review } \\
\text { (Peterson et al } \\
2017)\end{array}$ & $\mid \begin{array}{l}\text { Realist review } \\
\text { (Wong et al. 2013) }\end{array}$ & $\begin{array}{l}\text { Narrative review } \\
\text { (Jahan et al 2016) }\end{array}$ \\
\hline Question & Focused & $\begin{array}{l}\text { Broad or focused, } \\
\text { depending on } \\
\text { context }\end{array}$ & Often Broad & Often Broad & Broad \\
\hline $\begin{array}{l}\text { Search } \\
\text { strategy }\end{array}$ & $\begin{array}{l}\text { Systematic and } \\
\text { transparent }\end{array}$ & $\begin{array}{l}\text { Systematic and } \\
\text { transparent }\end{array}$ & $\begin{array}{l}\text { Systematic and } \\
\text { transparent }\end{array}$ & $\begin{array}{l}\text { Systematic and } \\
\text { transparent }\end{array}$ & $\begin{array}{l}\text { Should be systematic } \\
\text { but often not }\end{array}$ \\
\hline $\begin{array}{l}\text { Inclusion / } \\
\text { exclusion }\end{array}$ & A Priori & A Priori & Flexible & A Priori & $\begin{array}{l}\text { Should be systematic } \\
\text { but often not }\end{array}$ \\
\hline $\begin{array}{l}\text { Data } \\
\text { extraction }\end{array}$ & $\begin{array}{l}\text { Systematic, often } \\
\text { using a pro forma } \\
\text { or framework }\end{array}$ & $\begin{array}{l}\text { Systematic, often } \\
\text { using a pro forma } \\
\text { or framework }\end{array}$ & $\begin{array}{l}\text { Systematic, often } \\
\text { using a pro forma } \\
\text { or framework }\end{array}$ & $\begin{array}{l}\text { Systematic, often } \\
\text { using a pro forma } \\
\text { or framework }\end{array}$ & $\begin{array}{l}\text { Systematic, often } \\
\text { using a pro forma or } \\
\text { framework }\end{array}$ \\
\hline
\end{tabular}




\begin{tabular}{|c|c|c|c|c|c|}
\hline Synthesis & $\begin{array}{l}\text { Justification / } \\
\text { effectiveness } \\
\text { focus }\end{array}$ & $\begin{array}{l}\text { Justification, } \\
\text { descriptive, } \\
\text { contextualised } \\
\text { clarification }\end{array}$ & Descriptive & Clarification & Description \\
\hline $\begin{array}{l}\text { Implication } \\
\text { for practice }\end{array}$ & $\begin{array}{l}\text { Required and } \\
\text { tend to be implicit } \\
\text { It gives a } \\
\text { statement for } \\
\text { dissemination }\end{array}$ & $\begin{array}{l}\text { Required and not } \\
\text { implicit } \\
\text { It gives a general } \\
\text { recommendation }\end{array}$ & $\begin{array}{l}\text { Required and not } \\
\text { implicit }\end{array}$ & $\begin{array}{l}\text { Required and not } \\
\text { implicit }\end{array}$ & $\begin{array}{l}\text { Required and not } \\
\text { implicit }\end{array}$ \\
\hline
\end{tabular}

Table 1. Comparison of systematic review in clinical medicine and health education contexts

This does show that there is a difference in the scope of questions, as stated by Castillo et al (2018), with education reviews of all form tending to have broader questions. But when moving past that, all have a transparent plan to search for evidence and a requirement to present sufficient information to help the reader replicate and understand the process to find the evidence. Once this 'systematic' rigorous process for finding evidence has occurred, how this evidence is synthesised, managed or handled can embrace any method or world view. This reframing explains why BEME has recently published high quality reviews aligning with many of these review traditions (BEME 2017), which met the BEME requirement for a prospective peer reviewed protocol that ensured rigour. When the term systematic is understood in this way, rather than being incompatible with review and synthesis in education, this term denotes a form of methodological quality that is the same as we would expect in primary research. We believe that the field of health education review is vital to produce best evidence education with utility for educators and researchers. Within this field, a 'systematic' approach applies rigour to ensure the evidence found is complete and represents a best fit to the educational truth presented in the published literature. Having said this we are aware that in education there is no single truth. Unlike the EBM tradition of 
Cochrane systematic review, the educational truth is more complex, with multiple coexisting answers, contextual factors and different methods of investigation. Embracing the full range of synthesis techniques available is encouraged, but within a systematic search and data extraction framework.

The BEME collaboration, similarly to key journals in the field, welcomes all types of review submissions and suggests that all authors set out to describe rigorous reviews as 'systematic'. This aligns works with the systematic methodological principles that can underpin the wider range of review methodologies discussed, adding quality and supporting a culture of best evidence education 


\section{References}

Best Evidence Medical Education (BEME) Collaboration. BEME published reviews. Accessed October 21, 2017. Available from: https://www.bemecollaboration.org/Published+Reviews/

Bligh J, Anderson MB. 2000. Medical teachers and evidence. Med Educ, 34(3):162.

Castillo J , Park YS, Harris I, Cheung JJ, Sood L, Clark MD, Kulasegaram K, Brydges R, Norman G, Woods N. 2018. A critical narrative review of transfer of basic science knowledge in health professions education. Med Educ, 52: 592-604. doi:10.1111/medu.13519

Gordon M, Gibbs T. 2014. STORIES statement: publication standards for healthcare education evidence synthesis. BMC Med, 12(1):143.

Harden RM, Grant J, Buckley G, Hart IR. 2000. Best evidence medical education. Advances in Health Sciences Education, 5(1), 71-90.

Jahan N, Naveed S, Zeshan M, Adler J. (2016) How to conduct a systematic review: A narrative literature review. Cureus, 8(11) e864

Patricio M, vaz Carneiro. 2012. A. Systematic reviews of evidence in medical education and clinical medicine: is the nature of evidence similar? Med Teach,34(6):474-82. doi: 10.3109/0142159X.2012.682186. 
Peterson J, Pearce P, Ferguson L, Langford C. 2017. Understanding scoping reviews:

Definition, purpose and process. Journal of the American Association of Nurse

Practitioners, 29: 12-16

Wong G, Greenhalgh T, Westhorp G, Buchingham J, Pawson R. (2013). Rameses publication standards: realist syntheses. BMC Med,11:21

Van Der Vleuten CP, Dolmans DH, Scherpbier AJ. 2000. The need for evidence in education. Med Teach, 22(3):246-250. 